\title{
EXAMINING THE VISIBILITY OF SOCIAL RESPONSIBILITY ON THE WEBSITES OF HUNGARIAN STATE UNIVERSITIES
}

\author{
Adrienn REISINGER ${ }^{\mathrm{a}}$, Zsolt DÁNOS \\ a associate professor, Széchenyi István University, Kautz Gyula Faculty of Business and Economics, e- \\ mail: reisinger.adrienn@ga.sze.hu \\ b executive expert, Óbuda University, Rector’s Office, e-mail: danos.zsolt@gmail.com
}

Cite this article: Reisinger, A., Dános, Z. (2021). Examining the Visibility of Social Responsibility on the Websites of Hungarian State Universities. Deturope. 13(3), 58-72.

\begin{abstract}
The paper investigates university social responsibility at Hungarian universities by examining their websites. Although the concept of university social responsibility has existed for nearly 20 years, the scope of its research and theoretical literature still falls far short of that of corporate social responsibility. There is extant literature on the topic including case studies from around the world showing the importance of university social responsibility. Nevertheless, the scope of thematic analysis of the topic is very narrow with only a few pieces of comprehensive systematic research published so far, and the theoretical literature only highlights the work of some major researchers. Due to the complexity of the topic, the amount of previous literature attempting to explore the effects of university social responsibility is also limited. The aim of this paper is to investigate how terms relating to social responsibility appear on the websites of Hungarian universities. In autumn 2019 research was carried out involving twenty-one universities. The paper analyses how social responsibility is visible on university websites based on given keywords. The research employed quantitative content analysis. The hypothesis was that based on visibility the same university categories can be formed according to the size and profile of the institutions. According to the authors' present knowledge no such research has been carried out in Hungary so far. There are some university website researches in different countries but with different purposes with the special focus on sustainability. So the method of the present research is an attempt to find out how to measure the social responsibility visibility of universities and how to make categorizations based on the analyses. The limitation of the research is, among others, that universities have different search engines on their websites, which can lead to the misinterpretation of results. The main findings are that the visibility of social responsibility based on website analyses depends not only on the size and profile of the institutions; therefore, the investigation of visibility can contribute to the creation of new categories proving that social responsibility is far beyond the size or profile of the universities. The findings can help institutions develop the conscious communication of their social responsibility activity, and provide assistance to the research community.
\end{abstract}

Keywords: university social responsibility, Hungarian higher education, content analysis, website, visibility

\section{INTRODUCTION}

Nowadays, university missions have been amended and transformed with an unprecedented intensity. Regarding the mission changes, it is important to highlight the concept of the socalled academic revolutions (Etzkowitz, Webster, Gebhardt \& Castiano Terra, 2000), which enabled some university tasks to be supplemented with new functions. Thus, on the occasion of each revolution, besides education (teaching - learning), research and then the complex third 
mission appeared, which mostly involves the role of service provider, although its interpretation differs in literature. One of the new approaches of this third mission is university social responsibility which has received more attention in Hungarian higher education in recent years.

The goal of the paper is to ascertain how the term 'social responsibility' is visible on Hungarian university websites. A web content analysis was carried out in autumn 2019. The paper investigates twenty-one universities which were state-funded institutions at that time. By the time of publication only a handful remain state universities, while the others operate in a new form. This fact might have an effect on our results but we believe that as only a relatively short period has passed since the transformation, significant changes may not be experienced at the institutions. One limitation of the analysis could be that universities have different kinds of websites with different search engines, which can lead to misinterpretable results. Despite this fact we have chosen websites for analysis, because institutional websites are equally accessible to anyone from anywhere in the world and are the only forum of the institutions where they can make their activities equally visible. Institutional communication, therefore, becomes a potential area of university social responsibility, and at the same time the most important form of its expression. The study uses the concept of the visibility of activities by finding keywords to illustrate how website communication contributes to university social responsibility. The guiding principle of this idea is that communication of social responsibility can be a part of its realization. The study may be regarded as the first attempt to measure this visibility by finding keywords related to social responsibility.

The paper is structured as follows: First, it shows the topic of university social responsibility then it explains the research process and outlines the methods. The second part of the paper focuses on the results, draws conclusions and makes suggestions for the future.

\section{THEORETICAL BACKGROUND OF UNIVERSITY SOCIAL RESPONSIBILITY}

One of the milestones in the history of university social responsibility is the Magna Charta Universitatum from 1988, which lays out the values of the European university. Although it strongly emphasised the role of the academic sphere, it also highlighted the significance of shaping social values. The 1998 UNESCO Decree, the World Declaration on Higher Education for the Twenty-first Century: Vision and Action, which emphasised the social tasks of the entire higher education, was conceived in a much more democratic spirit (Veroszta, 2010). The document has significantly expanded the social tasks of higher education, thus greatly 
contributing to the process of including social tasks in the third mission of higher education institutions in addition to strengthening economic activities.

In the same vein, the 2009 ratification of the 1999 Decree (UNESCO Decree on The New Dynamics of Higher Education and Research for Societal Change and Development - Gurria, 2009) emphasised the social responsibility of higher education. The document reaffirmed the responsibility image of the 1998 Decree, in which the social responsibility of higher education aimed to serve not only the transfer of knowledge, but also a broader horizon of social wellbeing and development (Gurria, 2009). The 1998 Decree also greatly contributed to the spiritual search of the Bologna Process, which was launched in 1999 and aimed to reinforce social values with a stronger emphasis in higher education curricula (Jorge \& Peña, 2017).

Although the literature on university social responsibility is becoming wider and more diverse, the level of theoretical elaboration, in fact, is still far below the level of corporate social responsibility (CSR) (Jorge \& Peña, 2017). There is still much to be done in the modelling of university social responsibility, regardless of the fact that numerous studies have been dealing with various aspects of university responsibility for more than 20 years. The first appearance of the idea of university social responsibility is linked to Boyer (1996), who created the concept of Scholarship of Engagement, which can be considered a forerunner of university social responsibility. He argued that universities should be engaged more in tackling social, moral and economic problems, and suggested taking responsibility by disseminating the scholarship. Barker (2004) also suggested the distinction of scholarships on a practical basis.

Bonnen's work (1998) attempted to make an early interpretation. In addition, the spread of the term 'university (either state or private) civil engagement' also gained ground, being used as a kind of preliminary synonym of university social responsibility in literature (Esfijani, Hussain \& Chang, 2012). The research direction of the 2000s was mainly covered by the interpretation of sustainability within the university framework. These works mostly attempted to model university operation by demonstrating the aspects of sustainable development in university strategies (Lukman \& Glavic, 2007; Velazquez, Munugia, Platt \& Taddei, 2006). Similarly, the 1990 Talloires Declaration also sought to define the concept of the sustainable university providing a basis for the models.

In addition to the model of the sustainable university, university social responsibility as an independent concept only emerged in the 2000s, despite the fact that research on the phenomenon covered by the concept had already existed for a number of years. The initial models were described with respect to their similarities and differences regarding corporate social responsibility (Jorge \& Peña, 2017). On the emergence of the concept, the models drew 
primarily on the stakeholder theory being inspired by studies on corporate social responsibility (Jongbloed, Enders \& Salerno, 2008). Soon, the relevance of traditional stakeholders (e.g. students) was replaced by other stakeholders such as businesses (Benneworth \& Jongbloed, 2010), resulting in a wide range of definitions (Lo, Pang, Egri \& Li, 2017). In his study, Ford (2004) mapped the dimensions of higher education responsibility. According to Ford's interpretation, responsibility has been given a very broad context which is less observable in everyday practice, but irrespective of this, university social responsibility has a number of other definitions (Jorge \& Peña, 2017).

Having reviewed 15 years of literature, Jorge and Peña (2017) attempted to summarise the essence of university social responsibility. These days the most widespread definition of university responsibility seems to derive from Francois Vallaeys (2014), who can be considered one of the fathers of the concept, and also assisted the emergence of the Latin American university social responsibility movement in the mid-2000s. Central to the author's approach is the idea of 'think globally, do locally', local commitment and embeddedness, and democratic knowledge production. His concept is closely linked to the idea of the green university. In his view sustainability and the fair organisation of learning and research imply that science and knowledge are not marketable products, because they are directly responsible for value creation. Key institutions should have a moral responsibility in a global context. However, according to Vallaeys, universities need to reorganise their entire system to achieve this.

In conclusion, university social responsibility may be interpreted in several ways. It can be a strategic university organisational model, a vision, even a form of alliance interlacing universities, or a form of (self) organisation based on university traditions directly corresponding to social needs. In contrast, it can also involve some independent activities which offer an opportunity to provide some feedback to society in connection with university tasks (e.g. knowledge dissemination). In the same manner, it can cover a product which has its own management and literature, and is essentially a university function designed to support the relevance of university operations through marketing and PR tools, thus taking a similar form to the phenomena attacked by CSR critics. These are, however, only possibilities for interpretation, and we are closer to the correct interpretation if we consider university social responsibility as a collection category of phenomena, a concept encompassing them, which includes all segments of the university by covering its role as a social partner. Its main function is to provide service and support, it aims at non-profit and primarily social utility, and it involves such phenomena that cover the basic tasks of universities; however, they either go beyond its traditional frames or take on different forms and roles. 
According to our interpretation proposal, university social responsibility is the sum of the modern roles of higher education institutions, which is undertaken voluntarily or exceeds the required legal framework. University social responsibility is different from the first two basic tasks of universities (education and research); nevertheless, it is closely related to them. It is not linked to economic goals, but to ones that interpret social well-being in a broader sense.

\section{DATA AND METHODS}

The analysis presented in this paper is a part of an empirical research (Dános, 2021). The aim of the research is to determine in which forms and in what way university social responsibility manifests itself among universities in Hungary. The paper focuses on the analysis of university websites conducted in autumn 2019. It attempts to find an answer to how often terms related to university social responsibility appear on university websites and what the message of this visibility could be.

The research process was as follows:

- To the best of our knowledge, to date no research with a similar methodology has been conducted in Hungary or abroad ${ }^{1}$, thus first we had to develop the methodology of the analysis.

- Then we identified universities involved in the analysis.

- We drew up a hypothesis.

- We collected those keywords which were included in the website search.

- We carried out the website search in autumn 2019, which was followed by analysing the data.

- Finally, we drew up the conclusions and put forward suggestions.

In autumn 2019 state universities in Hungary included a relatively high number of institutions, so we decided to examine them. At the time of writing this paper only a few still belong to this category, the others are governed in a new form called public trust funds. This fact has imposed some limitation on our findings, in spite of the fact that not much time has passed since this change. So we believe that the findings on universities obtained in autumn 2019 may hold true and provide guidance for university leaders.

\footnotetext{
${ }^{1}$ At international level we have found some papers which present the results of website analyses of higher education institutions in different countries (e.g. Dade \& Hassenzahl, 2013; Hasim, Hashim, Ariff, Sapeciay \& Abdullah, 2018), but they have a focus on sustainability and their purpose is different from ours. So in Hungary our research is a completely new one, at international level it is a new approach how to analyse the university social responsibility visibility with the focus on creating groups from the analysed institutions based on the level of visibility.
} 
According to the Act CCIV of 2011 on National Higher Education in autumn 2019 there were 21 state universities. Their websites were involved into our research. The paper presents the results of the content analysis of the websites with respect to the degree of visibility in terms of university social responsibility. The research method seems to be suitable to make the communication activity of each university's social responsibility visible.

At first we formed groups from the analysed universities; this classification was the basis of our hypothesis. Based on previous research by Katalin Bander (2011) the categories of universities are as follows:

- Classical universities: University of Debrecen (DE), Eötvös Loránd University (ELTE), University of Pécs (PTE), University of Szeged (SZTE).

- Universities with wide but different professional profile compared to the classical universities: Budapest University of Technology and Economics (BME), University of Kaposvár (KE) ${ }^{2}$, University of Miskolc (ME), Óbuda University (ÓE), University of Pannonia (PE), University of Sopron (SoE), Szent István University (SZIE) ${ }^{3}$, University of Győr (SZE).

- Relatively small universities with special profile: University of Veterinary Medicine Budapest (ÁTE), Liszt Ferenc Academy of Music (LFZE), Hungarian University of Fine Arts (MKE), Hungarian Dance Academy (MTE), Moholy-Nagy University of Arts and Design Budapest (MOME), University of Theatre and Film Arts (SZFE), University of Physical Education (TE).

- Relatively large universities with special profile: National University of Public Service (NKE), Semmelweis University (SE) ${ }^{4}$.

Our hypothesis is that based on the analysis of the websites these categories form a relevant group with respect to social responsibility. As a result, we supposed that based on the visibility of social responsibility the same categories could be set up. A quantitative website analysis was carried out in the case of each institution. Based on the universities websites' search engines, we examined the frequency occurrence of the given keywords with reference to the topic social responsibility on the websites. The keywords were selected based on our former experience on this topic. The following keywords show the English equivalent of the words searched for on the websites of the universities:

\footnotetext{
${ }^{2}$ In 2021 it merged with Hungarian University of Agriculture and Life Sciences (MATE).

${ }^{3}$ In 2021 it merged with the Hungarian University of Agriculture and Life Sciences (MATE).

${ }^{4}$ The abbreviation of each university is based on their Hungarian name.
} 
- social responsibility,

- third mission,

- charity,

- sustainability,

- sustainable development,

- environmental protection,

- equal opportunity,

- voluntary,

- civil,

- indigent.

Using the search engine of the institutional websites each time meant different IT solutions and search ranges; therefore, it affected our results. Regarding this, it must be mentioned that in the case of some universities several thousands of website search results were generated, while in the case of other universities belonging to the same category based on size and profile only a minimum number of relevant content was found through the search engine, possibly less than a hundred. All this may have had a distorting effect on the results, thus it is important to state in advance that this methodology is only suitable for analysing visible and public content, namely it primarily measures the transparency of university social responsibility. Consequently, this method may not be suitable for analysing university social responsibility activities directly.

\section{RESULTS}

\section{The results of content analysis}

Following the survey and the aggregation of the data, we examined to what extent the results in the case of each institution show a similar picture within the predetermined four categories (based on the institutions' size and profile). If the examination had shown similar results within each category, this would have confirmed the adequacy of the predetermined institutional categories. However, we had to create new categories, since the visibility of social responsibility on the websites did not seem to merely follow the size and profile.

Table 1 shows the results of the website search in terms of the frequency occurrence of the given keywords on the universities' websites. 
Table 1 Keyword results on the websites of universities involved in the research, autumn 2019

\begin{tabular}{|l|c|c|c|c|c|c|c|c|c|c|c|}
\hline $\begin{array}{l}\text { Higher } \\
\text { education } \\
\text { institutions }\end{array}$ & $\begin{array}{c}\text { social } \\
\text { responsi- } \\
\text { bility }\end{array}$ & $\begin{array}{c}\text { third } \\
\text { mission }\end{array}$ & $\begin{array}{c}\text { chari- } \\
\text { ty }\end{array}$ & $\begin{array}{c}\text { sustai- } \\
\text { nability }\end{array}$ & $\begin{array}{c}\text { Sustai- } \\
\text { nable } \\
\text { develop- } \\
\text { ment }\end{array}$ & $\begin{array}{c}\text { Environ- } \\
\text { mental } \\
\text { protec- } \\
\text { tion }\end{array}$ & $\begin{array}{c}\text { equal } \\
\text { opportu- } \\
\text { nity }\end{array}$ & $\begin{array}{c}\text { Volun- } \\
\text { tary }\end{array}$ & civil & indigent & $\begin{array}{c}\text { Keywords } \\
\text { total }\end{array}$ \\
\hline DE & 0 & 6 & 2 & 7 & 3 & 8 & 9 & 8 & 19 & 2 & $\mathbf{6 4}$ \\
\hline ELTE & 56 & 37 & 5 & 122 & 115 & 54 & 96 & 145 & 259 & 391 & $\mathbf{1 , 2 8 0}$ \\
\hline PTE & 0 & 0 & 10 & 6 & 2 & 10 & 0 & 1 & 10 & 1 & $\mathbf{4 0}$ \\
\hline SZTE & 151 & 80 & 184 & 341 & 243 & 670 & 417 & 621 & 540 & 98 & $\mathbf{3 , 3 4 5}$ \\
\hline BME & 7 & 2 & 2 & 47 & 34 & 127 & 10 & 58 & 128 & 8 & $\mathbf{4 2 3}$ \\
\hline KE & 4 & 1 & 10 & 18 & 10 & 20 & 22 & 17 & 11 & 7 & $\mathbf{1 2 0}$ \\
\hline ME & 1 & 0 & 3 & 8 & 3 & 17 & 21 & 4 & 13 & 1 & $\mathbf{7 1}$ \\
\hline ÓE & 12 & 6 & 16 & 17 & 35 & 98 & 5 & 43 & 30 & 6 & $\mathbf{2 6 8}$ \\
\hline PE & 3 & 0 & 18 & 18 & 14 & 43 & 14 & 48 & 31 & 4 & $\mathbf{1 9 3}$ \\
\hline SoE & 22 & 6 & 29 & 68 & 32 & 175 & 27 & 42 & 52 & 18 & $\mathbf{4 7 1}$ \\
\hline SZIE & 4 & 0 & 0 & 40 & 33 & 157 & 6 & 58 & 93 & 8 & $\mathbf{3 9 9}$ \\
\hline SZE & 52 & 6 & 31 & 127 & 83 & 247 & 68 & 121 & 318 & 24 & $\mathbf{1 , 0 7 7}$ \\
\hline ÁTE & 1 & 0 & 1 & 0 & 2 & 13 & 1 & 18 & 32 & 2 & $\mathbf{7 0}$ \\
\hline LFZE & 0 & 0 & 11 & 0 & 0 & 0 & 1 & 0 & 4 & 2 & $\mathbf{1 8}$ \\
\hline MKE & 6 & 0 & 1 & 15 & 3 & 5 & 4 & 33 & 40 & 2 & $\mathbf{1 0 9}$ \\
\hline MTE & 0 & 0 & 0 & 0 & 1 & 1 & 8 & 1 & 1 & 0 & $\mathbf{1 2}$ \\
\hline MOME & 0 & 0 & 1 & 12 & 2 & 2 & 2 & 1 & 3 & 2 & $\mathbf{2 5}$ \\
\hline SZFE & 9 & 1 & 11 & 1 & 2 & 1 & 10 & 22 & 23 & 5 & $\mathbf{8 5}$ \\
\hline TE & 2 & 0 & 22 & 7 & 8 & 28 & 17 & 88 & 78 & 6 & $\mathbf{2 5 6}$ \\
\hline NKE & 16 & 2 & 10 & 51 & 62 & 24 & 12 & 45 & 131 & 4 & $\mathbf{3 5 7}$ \\
\hline SE & 33 & 2 & 108 & 222 & 111 & 620 & 1,080 & 2,010 & 1,600 & 344 & $\mathbf{6 , 1 3 0}$ \\
\hline Total: & 379 & 149 & 475 & 1,127 & 798 & 2,320 & 1,830 & $\mathbf{3 , 3 8 4}$ & $\mathbf{3 , 4 1 6}$ & 935 & $\mathbf{1 5 , 1 7 7}$ \\
\hline
\end{tabular}

Source: Compiled by the authors based on their research

As can be seen from the table, there are major differences between the institutions. There are universities where the number of the examined keywords reaches several thousand in number, while there are institutions where the values are around ten in number. The keywords 'voluntary' and 'civil' were the most common. The fact that the number of search results was very high at Semmelweis University played a large role in this, but even without this university, these two terms would be among the three keywords with the highest number of search results.

As the aggregated results demonstrate, the categories formed on the basis of size and profile do not comply with the results of the websites (to underpin it we present the highest and lowest search results from each category in Table 2). It means, for example, that a high number of keywords are only experienced in the case of relatively large universities and small universities do not necessarily have a low number of keywords. Based on our results we formed new university categories which are introduced in the next subsection.

\footnotetext{
${ }^{5}$ The institutions are listed in the order of the categories based on size and profile, and in alphabetical order within this.
} 
Table 2 The highest, lowest and average search results in university categories based on size and profile

\begin{tabular}{|l|c|c|c|c|c|c|}
\hline $\begin{array}{l}\text { Institutional } \\
\text { categories based on } \\
\text { size and profile }\end{array}$ & $\begin{array}{c}\text { The } \\
\text { institution } \\
\text { with the } \\
\text { highest } \\
\text { search } \\
\text { results }\end{array}$ & $\begin{array}{c}\text { Highest } \\
\text { search } \\
\text { results }\end{array}$ & $\begin{array}{c}\text { The } \\
\text { institution } \\
\text { with the } \\
\text { lowest } \\
\text { search } \\
\text { results }\end{array}$ & $\begin{array}{c}\text { Lowest } \\
\text { search } \\
\text { results }\end{array}$ & Difference & $\begin{array}{c}\text { Ave- } \\
\text { rage of } \\
\text { search } \\
\text { results }\end{array}$ \\
\hline $\begin{array}{l}\text { Classical } \\
\text { universities }\end{array}$ & SZTE & 3,709 & PTE & 40 & 3,669 & $1,273.25$ \\
\hline $\begin{array}{l}\text { Universities with } \\
\text { wide but different } \\
\text { professional profile } \\
\text { from the classical } \\
\text { universities SZE }\end{array}$ & 1,077 & ME & 71 & 1,006 & 377.75 \\
\hline $\begin{array}{l}\text { Relatively small } \\
\text { universities with } \\
\text { special profile }\end{array}$ & TE & 256 & MTE & 12 & 244 & 82.14 \\
\hline $\begin{array}{l}\text { Relatively large } \\
\text { universities with } \\
\text { special profile }\end{array}$ & SE & 6,130 & NKE & 357 & 5,773 & $3,243.5$ \\
\hline All categories & SE & 6,130 & MTE & 12 & 6,118 & $1,244.16$ \\
\hline
\end{tabular}

Source: Compiled by the authors based on their research

It can be seen that there are significant differences within each group. The biggest difference can be observed in the category of relatively large universities with a special profile. If we look at the average results, we could draw very false conclusions in several cases, as high averages can be linked to a far-reaching result, and not to a real average.

Although the keywords used in our research do not cover the whole scope of university social responsibility, it may be a proper method to show what universities consider important to communicate about themselves related to the topic of social responsibility. These contents are the indicators of the university's social responsibility. They show the clearest picture of its strategic position, elaboration and interpretation and how social responsibility is reflected in everyday activities. This is true even if the content is edited.

Tab. 3 illustrates the number of search results of university websites and the level of their visibility based on the data. As a result of these levels new university categories could be established. 
Table 3 The level of universities' visibility based on social responsibility

\begin{tabular}{|l|c|c|}
\hline Institution $^{\mathbf{6}}$ & $\begin{array}{c}\text { The number of search } \\
\text { results on the website }\end{array}$ & Level of visibility \\
\hline DE & 64 & low \\
\hline ELTE & 1,280 & high \\
\hline PTE & 40 & low \\
\hline SZTE & 3,709 & outstanding \\
\hline BME & 423 & medium \\
\hline KE & 120 & low \\
\hline ME & 71 & low \\
\hline OE & 268 & medium \\
\hline PE & 193 & low \\
\hline SoE & 471 & medium \\
\hline SZIE & 399 & medium \\
\hline SZE & 1,077 & high \\
\hline ATE & 70 & low \\
\hline LFZE & 18 & low \\
\hline MKE & 109 & low \\
\hline MTE & 12 & low \\
\hline MOME & 25 & low \\
\hline SZFE & 85 & low \\
\hline TE & 256 & medium \\
\hline NKE & 357 & medium \\
\hline SE & 6,130 & outstanding \\
\hline
\end{tabular}

Source: Compiled by the authors based on their research

\section{Visibility of social responsibility}

Awareness is one of the main elements of university social responsibility, or of any kind of responsibility. A university that does not or does not consciously select the related content is not aware of the significance and the effects of this phenomenon. The smaller the amount of relevant content available on a website, the less likely a university is to consciously manage its related activities. Although the indicator only partially measures visibility and qualifies communication, it also includes a very important condition; namely, that contents demonstrate existing activities which also illustrate the activity of the university related to social responsibility.

Based on our research we could set up the following four categories of universities:

1) Universities with outstanding visibility (institutions with at least 3,000 search results)

2) Universities with high visibility (institutions with at least 1,000 search results)

3) Universities with moderate visibility (institutions with at least 250 search results)

4) Universities with low visibility (institutions with less than 250 search results)

\footnotetext{
${ }^{6}$ The institutions are listed in the order of the categories based on size and profile, and in alphabetical order within this.
} 
Tab. 4 shows which universities fall into the above categories.

Table 4 Institutional categories based on keyword research in relation to university social responsibility

\begin{tabular}{|l|c|}
\hline \multicolumn{1}{|c|}{ Visibility categories } & Universities \\
\hline Universities with outstanding visibility & SZTE \\
& SE \\
\hline Universities with high visibility & ELTE \\
\hline Universities with moderate visibility & SZE \\
\hline & SoE \\
NKE \\
Universities with low visibility & BME \\
& ÓE \\
& SZIE \\
TE \\
\hline & ME \\
& MOME \\
DE \\
& PTE \\
KE \\
LFZE \\
PE \\
ATE \\
MKE \\
MTE \\
SZFE \\
\hline
\end{tabular}

Source: Compiled by the authors based on their research

The significance of the presence or the absence of terms varies by keyword, but it is important that only one search result can justify the presence of activities or thinking related to university social responsibility. Undoubtedly, it is important to mention the fact that if a keyword appears on the website of the institution, it does not mean that it will result in active activities. However, it is important to find keywords because their complete absence is very likely to indicate a lack of activities. It may not necessarily indicate the complete lack of related activities, but it rather implies the lack of organisational-level thinking about the topic, the conscious planning and implementation thereof, as well as the lack of communication and transparency.

The search results of universities' websites reflect the university social responsibility side of institutional life if the institution pays appropriate attention to its communication and their clear searchability. A lower number of search results corresponds to fewer publicly documented activities relating to social responsibility known at the institution, at least those which can be determined based on the keywords. In the case of some keywords, hundreds of search results were also found on some institutional websites, which probably indicates the importance of 
social responsibility at the university. This is especially the case at institutions where a large amount of news and more informal announcements are available on the websites.

With respect to our website research the following remarks should be made:

1) IT solutions relating to the design, the accuracy and search range of the website's search engine can greatly influence the results; therefore, it is possible to obtain different final results upon further investigation, both in the case of remarkably many and extremely few search results.

2) In the case of a large number of search results, a high search result was formed out of a vast amount of textual material. This may occur because of the large number of students or the significant role of social responsibility activities at the institutions in each field.

The display of social responsibility activity on websites is essential because the communication on the website is suitable to provide everyone with the same and equally important information about the given activities (depending, of course, on language and accessibility constraints). Furthermore, the information presented on the website shows the image that the institution wishes to present of itself in relation to social responsibility.

\section{CONCLUSIONS AND SUGGESTIONS}

The aim of the paper was to examine the visibility of university social responsibility on the websites of Hungarian universities. University social responsibility means that universities implement activities which exceed the traditional ones - namely education and research. Universities are concerned with both their immediate environment and the broader community and society at large. It is important for universities to not only be active in this field but also to communicate about it. In our research we chose to analyse websites of Hungarian universities. Examining websites is a kind of guide in terms of the interaction between society and the higher education institution; how this relationship works and how the socially responsible higher education institution appears to the outside world.

The demonstrated results contribute to empirical research among universities. We analysed twenty-one Hungarian universities which were state-funded at the time of the research, in autumn 2019. At the time of publication, however, only a few remain state universities as many are now managed by public trust foundations. We believe that this fact does not substantially 
influence our results, as only a short time period has passed since the transformation of the institutions.

Our research used content analysis of university websites. To the best of our knowledge, such a method has not been employed so far in Hungary. At international level there were some analyses of university websites but with different focuses. This means that our method of analysing this topic is an attempt to find out how to measure the visibility of social responsibility. Consequently, this method may seem to be a proper one to analyse the topic.

We have supposed that based on visibility we can have the same university categories as those based on the size and profile highlighted in the methodology part. However, we have found new forms of categorization. We divided universities into four groups in terms of their visibility: outstanding, high, moderate and low visibility institutions. Our results can be used for developing the awareness of institutional communication, since it becomes visible what institutions communicate to society about their activities.

As far as the limitation of the research is concerned, it can be noted that the results are significantly influenced by the IT backgrounds of the institutional websites, the ways in which they can be searched and the way in which the sub-websites are connected to each other. Websites are less able to show the full spectrum of social responsibility of a university, but they can describe the importance of the activities of a given institution. The limitation of the research was not only the differences due to IT and websites editing capabilities, but also the fact that universities make their content available at different communication levels. An interesting question arises regarding the conscious communication strategy behind the management of university websites and the financial resources available to the institution in this regard. Our research was made with the above mentioned limitations in mind; as a result, we focus on drawing conclusions from the frequency occurrence of keywords related to social responsibility on universities' websites.

Analyzing the communication of terms related to social responsibility can help universities follow and organize their activities and related processes as well as drawing attention to the social weight of social responsibility, self-image and mission of the institutions. Communication can support the marketing activities of the institution and attracting students by shaping the institutional image, providing additional market benefits for universities.

We put forward the following suggestions related to university social responsibility:

1) It can be important to recognize and consciously apply the importance and diverse functions of university social responsibility which can support modern university roles. 
2) The communication role of university websites related to social responsibility should be expanded, because this can provide information to the public.

3) Embracing the whole social responsibility approach can be managed by making social responsibility management a part of university strategy.

The findings of the paper provide an opportunity for further research, e.g. the examination of other types of institutions, and in the long run they can serve as a basis for extensive comparative analyses both in a domestic and international environment. The findings make it possible for institutional activities to become identifiable, collectable and unmatchable, thus helping clarify what social responsibility of an institution means in practice.

The importance of university social responsibility will increase with the changing roles of higher education institutions, and the focus will be for a while on defining the concept and identifying the related elements. In addition, it is also increasingly important to research the practical implications of social responsibility. We hope that our paper can contribute to this area and researchers and also practitioners can retrieve some theoretical and practical information related to university social responsibility.

\section{REFERENCES}

Bander, K. (2011). Vállalt küldetések az intézményi honlapok alapján. In: Hrubos, I. (Ed.), Mühelytanulmányok. NFKK Füzetek 8. (pp. 58-88). Budapest: Budapesti Corvinus Egyetem Nemzetközi Felsőoktatási Kutatások Központja.

Barker, D. (2004). The Scholarship of Engagement: A Taxonomy of Five Emerging Practices. Journal of Higher Education Outreach and Engagement, 9(2), 123-137.

Benneworth, P., \& Jongbloed, B. (2010). Who matters to universities? A stakeholder perspective on humanities, arts and social sciences valorisation. Higher Education, 59(5), 567-588.

Bonnen, J. T. (1998). The land grant idea and the evolving outreach university. In: Lerner, R. M. \& Simon, L. A. (Eds.), University-community collaborations for the 21st century: Outreach to scholarship for youth and families. (pp. 25-70). New York: Garland Press.

Boyer, E. L. (1996) The Scholarship of Engagement. Bulletin of the American Academy of Arts and Sciences, 49(7), 18-33.

Dade, A., \& Hassenzahl, D. M. (2013). Communicating sustainability A content analysis of website communications in the United States. International Journal of Sustainability in Higher Education, 14(3), 254-263.

Dános, Z. (2021). A társadalmi felelösségvállalás formái a magyar felsőoktatásban. Doctoral dissertation, Győr: Széchenyi István University. 247. p. https://rgdi.sze.hu//images/RGDI/ honlapelemei/fokozatszerzesi_anyagok/Doktori\%20\%C3\%A9rtekez\%C3\%A9s D\%C3\%A1nos_Zsolt.pdf

Esfijani, A., Hussain, F. K., \& Chang, E. (2012). An approach to university social responsibility ontology development through text analyses. Paper presented at the IEEE 5th International Conference on Human System Interactions, IEEE-HSI-2012. 
Etzkowitz, H., Webster, A., Gebhardt, C., \& Castiano Terra, B. R. (2000). The future of the university and the university of the future: evolution of ivory tower to entrepreneurial paradigm. Research Policy, 29(2), 313-330.

Ford, D. F. (2004). The Responsibilities of Universities in a Religious and Secular World. Studies in Christian Ethics, 17, 22-37.

Gurria, A. (2009). The New Dynamics of Higher Education and Research For Societal Change and Development. Introductory Remarks. UNESCO World Conference on Higher Education. Retrieved (10 06 2020) from https://www.oecd.org/education/thenewdynamicsofhighereducationandresearchforsociet alchangeanddevelopment.htm

Hasim, M. S., Hashim, A. E., Ariff, N. R. M., Sapeciay, Z., \& Abdullah, A. S. (2018). Commitment to sustainability: A content analysis of website for university organisations. IOP Conf. Series: Earth and Environmental Science, 117, 012046

Jongbloed, B., Enders, J. \& Salerno, C. (2008). Higher education and its communities: Interconnections, interdependencies and a research agenda. Higher Education, 56(3), 303-324.

Jorge, M. L. \& Peña, F. J. A. (2017). Analysing the literature on university social responsibility: A review of selected higher education journals. Higher Education Quarterly, 71, 302319.

Lo, C. W-H., Pang, R. X., Egri, C. P., \& Li, P. H-Y. (2017). University Social Responsibility: Conceptualization and Assessment Framework. In: Shek, D.T. L. \& Hollister, R. M. (Eds.), University Social Responsibility and Quality of Life. Quality of Life in Asia, 8, (pp. 37-62). Singapore: Springer.

Lukman, R., \& Glavic, P. (2007). What are the key elements of a sustainable university? Clean Technologies and Environmental Policy, 9, 103-114.

Magna Charta Universitatum (1988) Bologna, $18^{\text {th }}$ of September. Retrieved (22 03 2019) from http://www.felvi.hu/pub_bin/kep/felsooktatasimuhely/magna_charta_magyar.pdf

Vallaeys, F. (2014). University Social Responsibility: a mature and responsible definition. In: Global University Network for Innovation (Ed.) Higher Education in the World 3. Higher Education: New Challenges and Emerging Roles for Human and Social Development. (pp. 88-96). Palgrave Macmillan: GUNI Series on the Social Commitment of Universities.

Velazquez, L., Munugia, N., Platt, A., \& Taddei, J. (2006). Sustainable university: what can be the matter? Journal of Cleaner Production, 14(9-11), 810-819.

Veroszta, Z. (2010) Felsőoktatási értékek - hallgatói szemmel. A felsőoktatás küldetésére vonatkozó hallgatói értékstruktúrák feltárása. Budapest: Budapesti Corvinus Egyetem, Társadalomtudományi Kar, Szociológia Doktori Iskola.

World Declaration on Higher Education for the Twenty-first Century: Vision and Action (1998). Retrieved (10 $06 \quad 020)$ from https://unesdoc.unesco.org/ark:/48223/pf0000113779?posInSet=3\&queryId=777790658b38-4a19-b92b-995515487455 